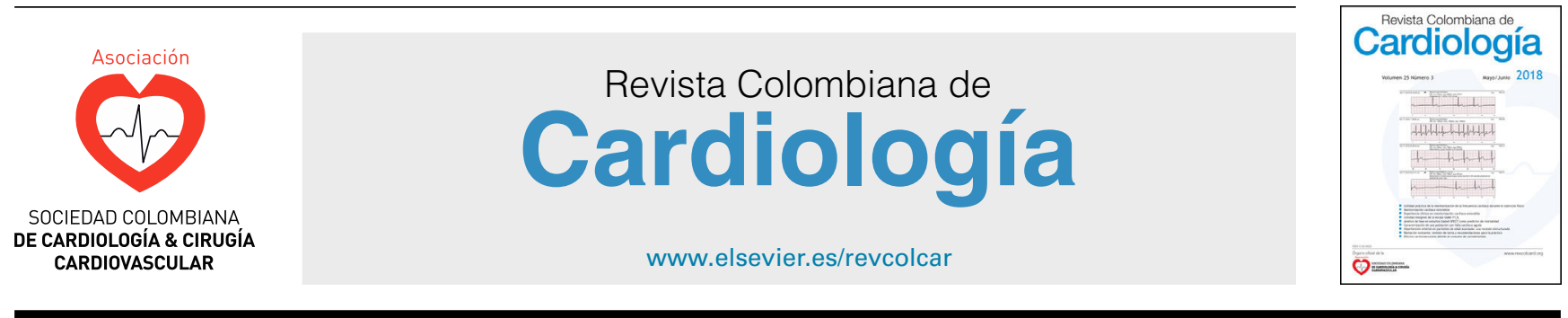

PAEDIATRIC CARDIOLOGY - CASE PRESENTATIONS

\title{
Unusual distal right pulmonary artery origin from right ductus arteriosus with uncommon left-sided aortic arch
}

\author{
Esther Cambronero-Cortinas ${ }^{\mathrm{a}, *}$, Natalia Rivero-Jiménez ${ }^{\mathrm{b}}$, Montserrat Bret-Zurita ${ }^{\mathrm{c}}$, \\ Pedro Moratalla-Haro ${ }^{\mathrm{d}}$, Luis García-Guereta Silva ${ }^{\mathrm{e}}$
}

\author{
a Departamento de Cardiología, Royal Brompton and Harefield Hospital, Londres, Inglaterra \\ b Departamento de Cardiología Pediátrica, Hospital Ramón y Cajal, Madrid, España \\ ' Departamento de Radiología Pediátrica, Hospital Universitario "La Paz', Madrid, España \\ ' Facultad de Enfermería, Universidad de Castilla-La Mancha, Albacete, España \\ e Departmento de Cardiología Pediátrica, Hospital Universitario 'La Paz", Madrid, España
}

Received 30 December 2017; accepted 3 August 2018

Available online 10 December 2018

\section{KEYWORDS \\ Bilateral ductus \\ arteriosus; \\ Unilateral absence of \\ the proximal right \\ proximal pulmonary \\ artery; \\ Pulmonary \\ hypertension}

\begin{abstract}
A bilateral persistent ductus arteriosus with right proximal pulmonary artery agenesis is a very unusual anatomic variant. These malformations are assumed to occur during the transformation of the sixth aortic arch with the pulmonary trunk in the development of the aorta and its branches.

A 2-months preterm baby was referred by severe bronchopulmonary dysplasia. Transthoracic echocardiography showed a large pulmonary trunk and left pulmonary artery. No right proximal pulmonary artery was found. Cardiac computed tomography study showed bilateral ductus arteriosus. The right proximal pulmonary artery was originated from an arterial structure coming off the right subclavian artery, a right ductus arteriosus. The aortic arch was left-sided, with a peculiar variant at the exit of the supraaortic vessels. Right subclavian artery emerged as the first supraaortic vessel, followed by a common trunk, giving rise to both carotids and the left subclavian artery as the last vessel. Right lung was hypoplastic with interstitial disease.

The calibre of the right proximal pulmonary artery was inadequate to perform a corrective surgery. LDA closure was performed, keeping a prostaglandin infusion to maintain right ductus arteriosus patency until right proximal pulmonary artery size will be big enough to perform a successful surgical reconstruction. Unfortunately, right ductus arteriosus became narrow at its origin and she developed severe pulmonary hypertension and the patient died.

(C) 2018 Sociedad Colombiana de Cardiología y Cirugía Cardiovascular. Published by Elsevier España, S.L.U. This is an open access article under the CC BY-NC-ND license (http:// creativecommons.org/licenses/by-nc-nd/4.0/).
\end{abstract}

Abbreviations: LPA, Left pulmonary artery; MDCT, Cardiac Multidetector Computed Tomography; PDA, Left persistent ductus arteriosus; RDA, Right ductus arteriosus; RPA, Right pulmonary artery; RSA, Right subclavian artery.

* Corresponding author.

E-mail address: E.Cambronero-Cortinas@rbht.nhs.uk (E. Cambronero-Cortinas). 


\section{PALABRAS CLAVE}

Ductus arterioso

bilateral;

Agenesia unilateral

de la arteria

pulmonar derecha;

Hipertensión

pulmonar

\section{Inusual origen de la parte distal de la arteria pulmonar derecha en un ductus arterioso derecho en arco aórtico izquierdo no común}

Resumen El ductus arterioso bilateral con agenesia proximal de la arteria pulmonar derecha es una variante anatómica rara producida por alteraciones de la transformación del sexto arco aórtico en las arterias pulmonares, la aorta y sus vasos, durante el desarrollo embrionario.

Se presenta el caso de un bebé prematuro de dos meses, que fue derivado a nuestro hospital por displasia broncopulmonar severa. El ecocardiograma transtorácico no identificó el origen de la arteria pulmonar derecha. El estudio por tomografía computarizada cardiaca mostró ductus arterioso bilateral e identificó el origen distal de la arteria pulmonar derecha en una rama de la arteria subclavia derecha, identificada como ductus arterioso derecho. El pulmón derecho era hipoplástico y presentaba alteraciones intersticiales. A su vez, el patrón de los vasos supraaórticos era anómalo. El primer vaso correspondió a la arteria subclavia derecha, seguido por tronco común de ambas carótidas y por último la arteria subclavia izquierda.

El calibre de la arteria pulmonar derecha fue inadecuado para realizar una cirugía correctiva, por lo cual se decidió cerrar el ductus arterioso izquierdo y mantener infusión de prostaglandina hasta que la arteria pulmonar derecha tuviera un calibre adecuado para la cirugía. Infortunadamente, el ductus arterioso derecho se cerró en su origen, desarrollándose hipertensión pulmonar severa y la paciente falleció.

(c) 2018 Sociedad Colombiana de Cardiología y Cirugía Cardiovascular. Publicado por Elsevier España, S.L.U. Este es un artículo Open Access bajo la licencia CC BY-NC-ND (http:// creativecommons.org/licenses/by-nc-nd/4.0/).

\section{Clinical case}

A bilateral persistent ductus arteriosus with right proximal pulmonary artery agenesis is a very unusual anatomic variant. These malformations are assumed to occur during the transformation of the sixth aortic arch with the pulmonary trunk in the development of the aorta and its branches. ${ }^{1,2}$ Few cases of this anomaly have been published in the literature. We present one patient treated in our hospital.

A 2-months preterm baby with $1.584 \mathrm{~kg}$ of weight was referred by severe bronchopulmonary dysplasia. Transthoracic echocardiography (TTE) did not show intracardiac defects. The right ventricle gave rise to a large pulmonary trunk, which continued as a singlewide pulmonary artery (PA) to the left lung. A left ductus arteriosus (LDA) was in the usual location but no origin of the right PA (RPA) was found. The aortic arch was left-sided and a systemic-pulmonary collateral apparently arose from the brachiocephalic trunk to right hemithorax.

MDCT study showed absence of connection of the RPA from the pulmonary trunk. The RPA originated from an arterial structure coming off the right subclavian artery (RSA), a right DA (RDA). The aortic arch was left-sided, with a peculiar variant at the exit of the supraaortic vessels. RSA emerged as the first supraaortic vessel, followed by a common trunk, giving rise to both carotids and the left subclavian artery as the last vessel. Right lung was hypoplastic with interstitial disease (fig. 1).

The calibre of the RPA was inadequate to perform a corrective surgery. LDA closure was performed, keeping a prostaglandin infusion to maintain RDA patency until RPA size was big enough to perform a successful surgical reconstruction.
Unfortunately, RDA became narrow at its origin and she developed severe pulmonary hypertension with heart failure (fig. 2), due to both parenchymal lung damage and high pulmonary flow. There was no response to pulmonary vasodilators, so she died.

\section{Discussion}

To the best of our knowledge, there are no relevant reports about double patent ductus arteriosus, with a common origin of the both carotid arteries from left-sided aortic arch with no aberrant right subclavian artery and unilateral proximal absence of the right proximal pulmonary artery with distal origin in right ductus arteriosus that take off from RSA.

In 1868 , the first case of absence of the proximal pulmonary artery was reported. This cardiovascular anomaly is generally associated with other cardiovascular malformations, mainly Tetralogy of Fallot, common arterial trunk and septal defects. ${ }^{3}$ The prevalence in the general population has been reported to be about 1 of 200,000 individuals and ductal origin of the pulmonary arteries occurs in $1.5 \%$ of the cases.

Isolated discontinuity of a pulmonary branch is usually located contralateral to the aortic $\operatorname{arch}^{3}$ and these patients may remain asymptomatic or present cardiac manifestations such us recurrent pneumonias, haemoptysis, or pulmonary hypertension. ${ }^{4}$

Double ductal system is much more typically found with a right aortic $\operatorname{arch}^{5}$ and this anomaly is highly associated with non-confluent pulmonary arteries. The diagnosis should be suspected in a patient with radiologic findings such us absence of hilar shadow, diminution of vascular marks and hemidiaphragm elevation of the affected side, with homolateral mediastinal deviation. ${ }^{6}$ 


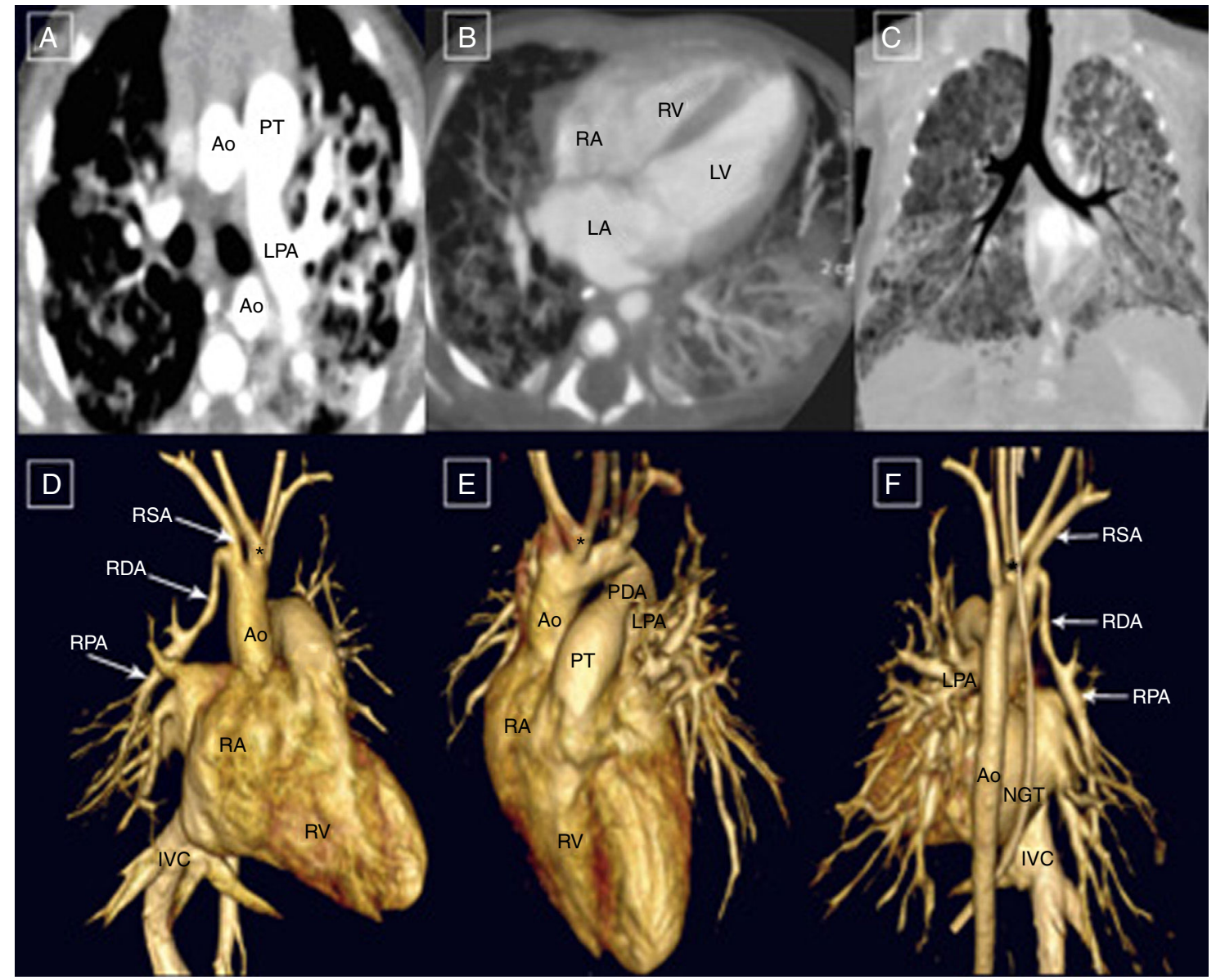

Figure 1 Diagnosis of proximal RPA absence with distal origin in RDA. A: This axial slice is showing absence of proximal RPA origin from the pulmonary trunk. B: Axial projection confirmed normal biventricular cavity size. C: Minimal MIP showed normal situs solitus and right lung hypoplasia with interstitial disease. D: Antero-lateral VR of the heart that confirmed absence of proximal RPA originating from the pulmonary trunk. E: Anterior VR showing left PDA. F: Posterior VR characterized distal RPA support by RDA. RDA: Right ductus arteriosus; PDA: Left ductus arteriosus; PT: Pulmonary trunk; RPA: right pulmonary artery; LPA: Left pulmonary artery; RA: Right Atrium; RV: Right ventricle; IVC: Inferior vena cava; Ao: Aorta; Asterisk: Common origin of both carotids.

TTE is the most often used screening tool for anatomic evaluation. However, in the last few years, MDCT has emerged as a non-invasive imaging modality providing comprehensive and accurate evaluation of these very complex anatomical malformations in order to perform the correct diagnosis and monitoring therapeutic efficacy or complications. Moreover, in our patient was very helpful due the combination of anomalous RPA origin with anomalous aortic archś (AA) branches. The first AAs branch was RSA and left subclavian artery took off as third branch, combined with common carotid arteries origin. Right aberrant subclavian artery is usually related with these $A A$ anomaly. ${ }^{2}$

In this setting, PGE1 perfusion served to repermeabilize the ductal structure. So far, this treatment allowed us to maintain adequate perfusion to the right lung. Thereby, the patient could have some time for the correct development of the pulmonary vascular bed until corrective surgery could be performed.

On the bases of these findings, firstly, we recommend cardiac screening in patients with unilateral pulmonary hypoplasia with TTE. MDCT should be considered to assess very complex anatomy and if clinical concern and/or suspicion remains. Once we have the diagnosis, aggressive treatment with PGs therapy may be maintained until the patient could be surgical repaired and early corrective surgery might be recommended in order to avoid late complications as well.

Overall, the origin of distal RPA from RDA is a rare congenital developmental anomaly due to a failure in the connection of the sixth aortic arch with the pulmonary trunk. TTE and MDCT might be considered in order to perform the correct diagnosis. However, treatment remains difficult when a symptomatic low-weight baby with pulmonary disease is affected. 


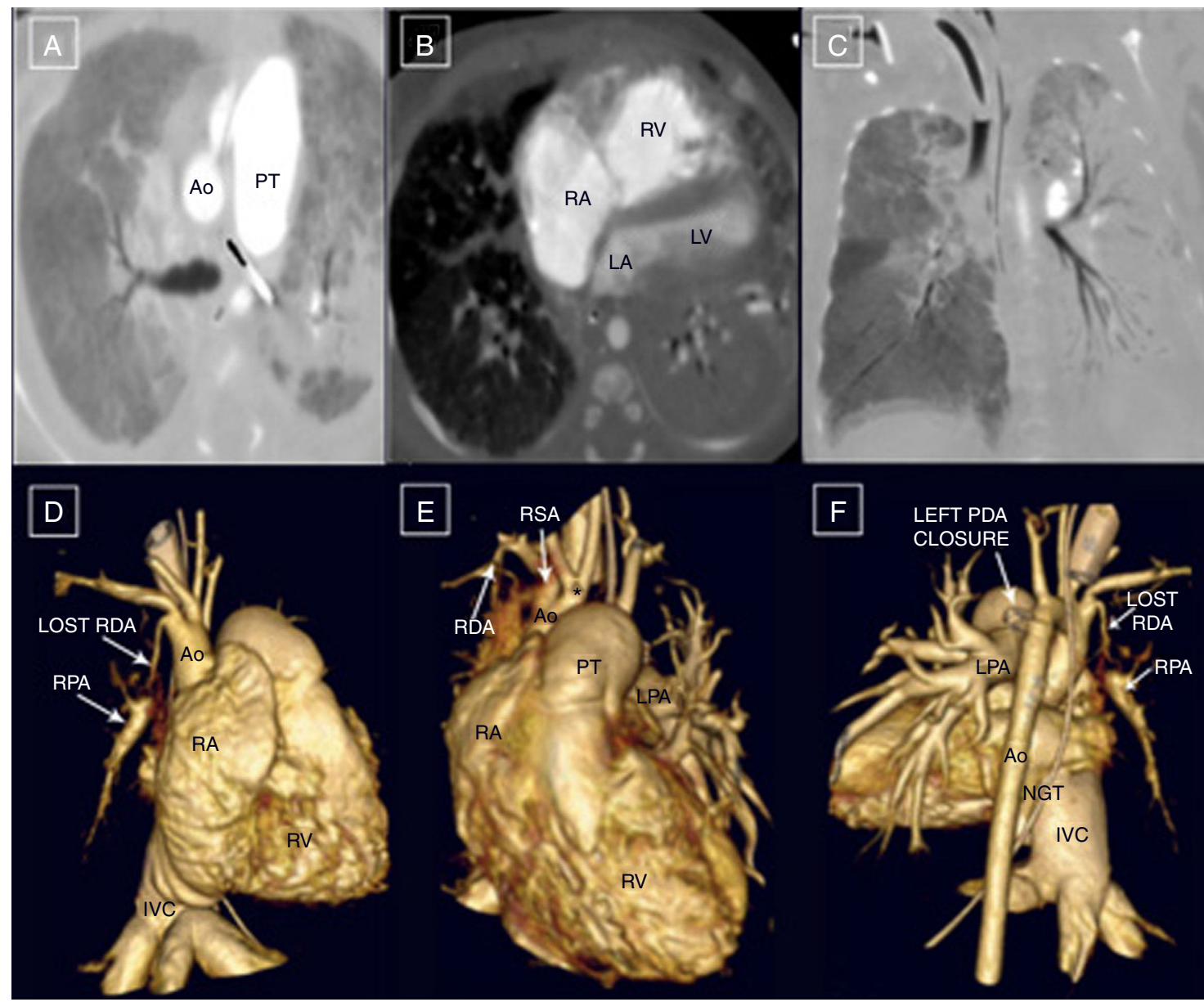

Figure 2 Evolution after left PDA closure. A: This axial stack displayed marked dilatation of pulmonary trunk. B: This axial projection manifested right chambers dilatation and small left chambers. C: Coronal MIP view showed right parenchymal hypoperfusion and left lung increase in density with patchy consolidation. D: Anterior VR reconstruction pointed dilatation of right chambers, pulmonary trunk, and IVC. E: This antero-lateral VR showed that RDA was lost. F: Posterior VR confirmed dilatation of all the right chambers and losing RDA. RDA: Right ductus arteriosus; PDA: Left ductus arteriosus; PT: Pulmonary trunk; RPA: right pulmonary artery; LPA: Left pulmonary artery; RA: Right Atrium; RV: Right ventricle; IVC: Inferior vena cava; Ao: Aorta.

\section{Conflict of interest}

None.

\section{Acknowledgements}

To all Pediatric Cardiology Department in "La Paz" Hospital.

\section{References}

1. Wang ZW, Liu WY, Zhang BR, editors. Cardiac Surgery. Embryonic development of the heart. Beijing: People's Medical Publishing House; 2003. p. 18-20.
2. Ergun O, Tatar IG, Birgi E, Durmaz HA, Akçalar S, Kurt A, et al. Angiographic of branching pattern and anatomy of the aortic arch. Turk Kardiyol Dern Ars. 2015;43:219-26.

3. Presbitero P, Bull C, Haworth SG, de Leval MR. Absent or occult pulmonary artery. Br Heart J. 1984;52:178-85.

4. Ten Harkel AD, Blom NA, Ottenkkamp J. Isolated unilateral absence of a pulmonary artery: a case report and review of the literature. Chest. 2002;122:1471-7.

5. Luetmer PH, Miller GM. Right aortic arch with isolation of the left subclavian artery: case report and review of the literature. Mayo Clin Proc. 1990;65:407-13.

6. Freedom RM, Moes CA, Pelech A, Smallhorn J, Rabinovitch M, Olley PM, et al. Bilateral ductus arteriosus (or remnant): an analysis of 27 patients. Am J Cardiol. 1984;53:884-91. 